\title{
Design and Implementation of Portable and Prospective Embedded System and loT Laboratory Kit Modules
}

\author{
Era Madona ${ }^{1}$, Yulastri ${ }^{1}$, Anggara Nasution ${ }^{1}$, and M.Irmansyah ${ }^{1}$ \\ ${ }^{1}$ Jurusan Teknik Elektro, Politeknik Negeri Padang, 25168, Padang - Sumatera Barat, Indonesia \\ Corresponding author: Era Madona emadona38@gmail.com
}

\begin{abstract}
Laboratory practice activities are important activities for vocational education The learning process is not optimal because laboratory equipment is inadequate. The purpose of this research is to design and implement a new design of a low-cost, portable and prospective laboratory kit module. Laboratory kits are made easy to assemble, with relatively small dimensions. and suitable for use in laboratories with limited experimental space and funds. The research stages are carried out starting with needs analysis, hardware design, software design and overall testing. The test results of the DHT 11 temperature sensor can read the temperature and humidity index whose data is in the form of digital data and is displayed on the LCD. The PWM of the DC motor and the direction of rotation of the motor can be controlled using the DHT11 sensor. The keypad can control the direction of rotation of the servo motor so that students are expected to be able to provide authentication through a password with a keypad. Testing the module kit for data communication using the local network Testing the module kit for data communication using the local network is able to control the motor and relay even though there is still a delay in sending data this is due to the condition of the internet network at the time of testing. The results of the economic analysis show that the module is cheaper and portable. The overall test results work well. It is hoped that this module will encourage students to be able to create technological innovation applications based on embedded systems and IoT which will lead to the creation of technology among students.
\end{abstract}

INDEX TERMS Laboratory kit module, embedded system, IoT, Portable

\section{INTRODUCTION}

Embedded system is a computer system specifically designed for a specific purpose in order to improve the function of a machine. The development of information technology today is marked by the presence of the Internet of Things (IoT). IoT is an internet service that is integrated with the use of certain types of sensors [1][2]. Currently, IoT-based embedded systems have been widely applied such as for health monitoring [3-6] natural disasters [7-10] agriculture [11-13] and the industrial world [14-16]. The ability of students to apply embedded systems is needed, especially in the world of working and other things. It was successfully applied to the Undergraduate Embedded System Education at Carnegie Mellon [17]. In the academic activity, many studies have been carried out on the Embedded system for its development [18] implementation of servo motor control [10], use of sensors [19] and DC motors [20]. Laboratory practice activities are important activities for vocational education related to their experience in learning, thinking and solving problems [21]. Limited equipment is a major problem for students causing students to not be able to experience learning. The learning process is not optimal because of inadequate laboratory equipment. Computer simulation is an alternative for these problems [22] such as LabView [23], Matlab [24] and others. This software uses a license whose budget is not affordable by the laboratory. The use of plants for IoT-based industries for learning is impossible because it is very expensive. In this study, a new design for a low-cost, portable laboratory kit module was created for use in embedded systems and data communication practicum in the Electronic Engineering Study Program, Electrical Engineering Department.

Some related researches are study conducted by [22] showed an increase in student learning scores of $7.8 \%$ by using 
the module for embedded systems practicum activities. Making a cargo transporting robot [25] applied it method as a learning medium for microcontrollers, the results of the study show that the prototype made can be used in the teaching and learning process. A similar study was also conducted by [26] making the MCS51 microcontroller practical module which is portable and lower power consumption. In this study, a module was made to support the teaching process of embedded systems and IoT with a single PCB, portable and low cost. Developments of previous studies are (1). Practical modules are integrated in one PCB board with low power consumption and portable. (2). Integrated with LAN Modules, Wireless and sensors for Internet of Thing (IoT) applications. Miniaturization is the contribution of this research.

The purpose of this research to design and implementation a new design of a low-cost, portable and prospective laboratory kit module. Laboratory kits are made easy to assemble, with relatively small dimensions and suitable for laboratories with limited experimental space and funds. This module kit consists of arduino embedded system modules, mcu nodes, LAN modules for data communication and sensors with various features. It is hoped that this module will encourage students to be able to create technological innovation applications based on embedded systems and IoT which will lead to the creation of technology in between students.

\section{MATERIALS AND METHODS}

This research was conducted at the Microcontroller Laboratory of the Department of Electrical Engineering, Padang State Polytechnic. The method used in this research is hardware design, software design, hardware testing, software and analysis. The stages of the research can be seen in Figure 1 .

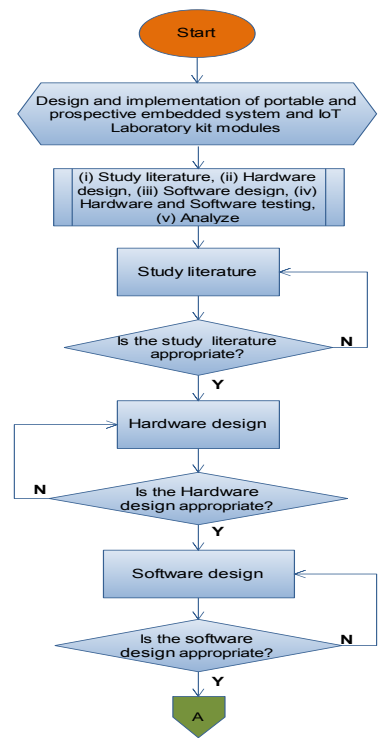

FIGURE 1. Research methods of Design and Implementation of Portable and Prospective Embedded System and IoT Laboratory Kit Modules

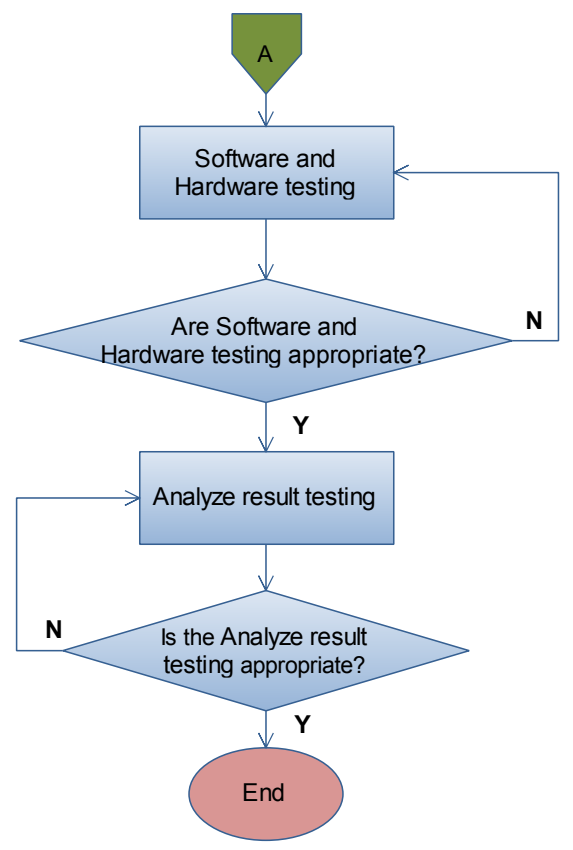

\section{A. SYSTEM DESIGN}

The learning of Embedded Systems and data communication (IoT) are needed practical activities, so students become more understand and have skills while they graduate. Based on the results of the analysis, we propose this practicum module to overcome the previously identified problem, namely the absence of an Embedded System and data communication (IoT) practicum module. This module consists of input block, process block and output block as shown in Figure 2.

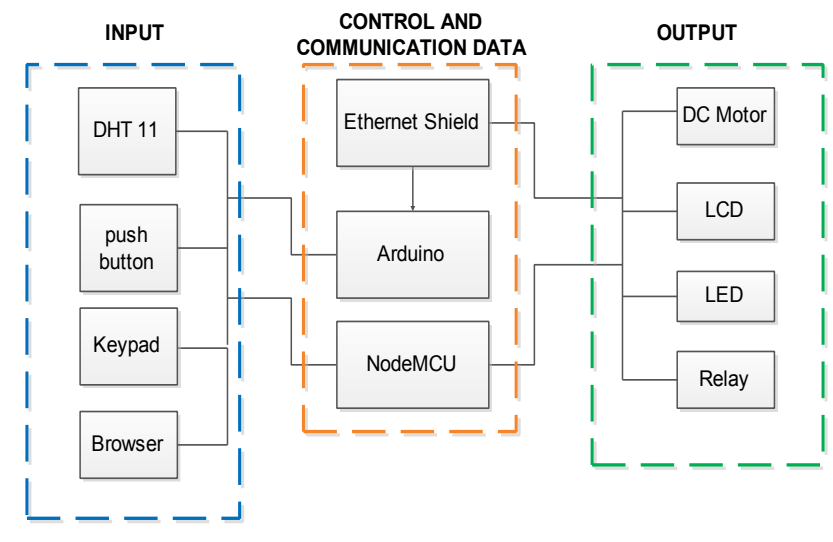

FIGURE 2. Block Diagram of the practicum module

Based on Figure 2, the operation of this practicum module is divided into three parts, namely input, process and output. Input consists of DHT, push button, keypad and browser. DHT11 reads the temperature and sent the data to the Arduino digital pin. Browser provides input to Arduino via Ethernet network and Browser provides input to NodeMCU via wireless network. Once data receive, it will processed on the Arduino uno or NodeMCU according to its use. The using of Arduino is required if the input only wants to be processed 
directly to the output and using Ethernet communication. But if the system use the wireless feature as an output, it can use NodeMCU. Furthermore, the data has been processed by the microcontroller is issued to several available outputs including LCD, DC Motor, LED and Relay. The LCD will display characters in the form of text or numbers. The DC motor works to issue a movement that can be adjusted via PWM. LED to display an indicator in the form of light. The relay works as an automatic switch.

\section{B. HARDWARE DESIGN}

The design process starts with the creation of the circuit. This circuit consists of a temperature and humidity detector using a DHT11 sensor [11], push button, LCD, Led, relay and dc motor. DHT11 is connected to the VCC Pin on the Arduino Uno to provide an input voltage of 5V, then the DHT 11 GND Pin is connected to the Arduino GND Pin, the DHT 11 Data Pin is connected to Arduino Pin 2. Then on the LCD, 4 PINs are used, namely VCC, GND, SDA and SCL. The VCC and GND pins are connected to the customized pins on the Arduino, the SDA Pins are connected to the Analog A4 Pins and the SCL Pins are connected to the Analog A5 Pins. Then on the Motor pins that are used only the Positive Motor and Negative Motors are connected to the adjusted Pins on the Arduino Pins as shown in figure 3.

In the LED circuit, the LED Pin 1 is connected to the digital pin 10 on the Arduino Uno and the GND Pin is connected to the Arduino GND Pin. LED 2 is connected to digital pin 11 on Arduino Uno and GND Pin is connected to Arduino GND Pin, LED 3 is connected to digital pin 12 on Arduino Uno and GND Pin is connected to Arduino GND Pin, Data Relay pin is connected to digital pin 3 .

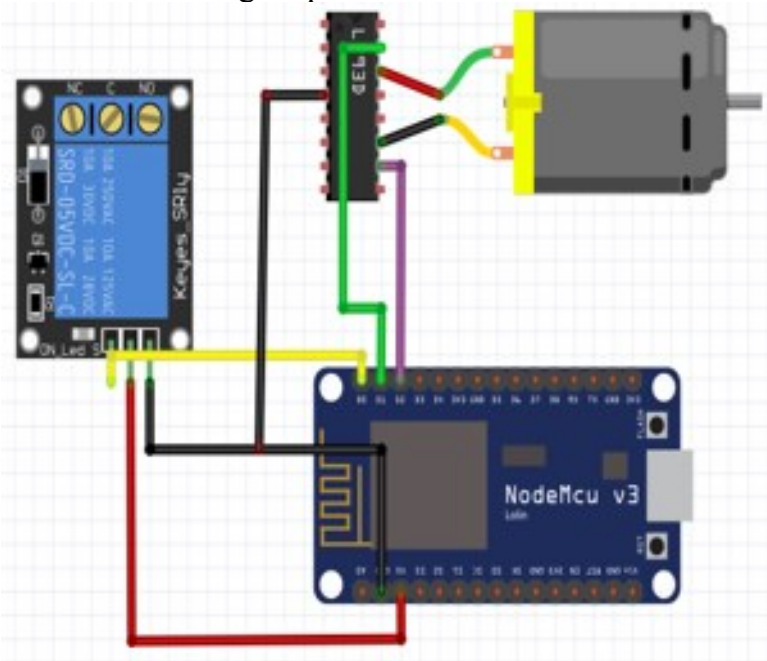

(a)

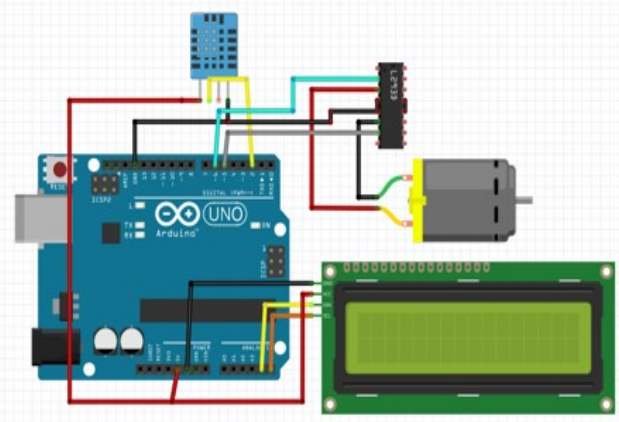

(b)

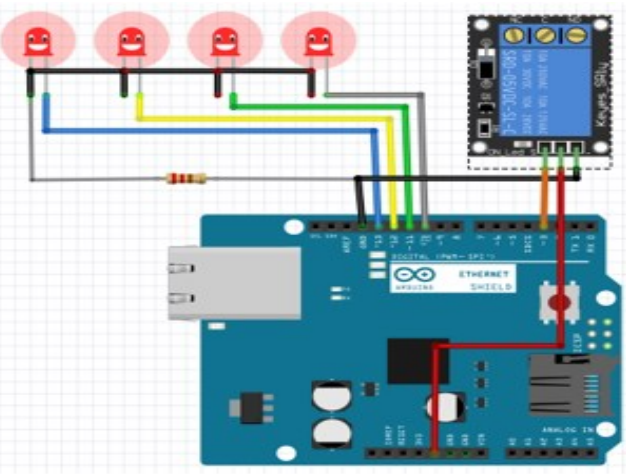

(c)

FIGURE 3. The practical module electronics circuit: (a) NODEMCU Circuit to Motor and Relay; (b) DHT11 Circuit, LCD and Motor to Arduino Uno; (c) LED and Relay circuit to Arduino using Ethernet Network

In the LED circuit, the LED Pin 1 is connected to the digital pin 10 on the Arduino Uno and the GND Pin is connected to the Arduino GND Pin. LED 2 is connected to digital pin 11 on Arduino Uno and GND Pin is connected to Arduino GND Pin, LED 3 is connected to digital pin 12 on Arduino Uno and GND Pin is connected to Arduino GND Pin, Data Relay pin is connected to digital pin 3 . As for DC motor circuit, Data Pin 1 on the DC Motor is connected to Pin D1 NODEMCU and Data Pin 2 is connected to pin D2 NODEMCU. The Data Relay pin is connected to the D0 pin of the NODEMCU and the VCC and GND pins correspond to the VCC pin and the GND pin of the NODEMCU. The practicum module design can be seen in Figure 4.

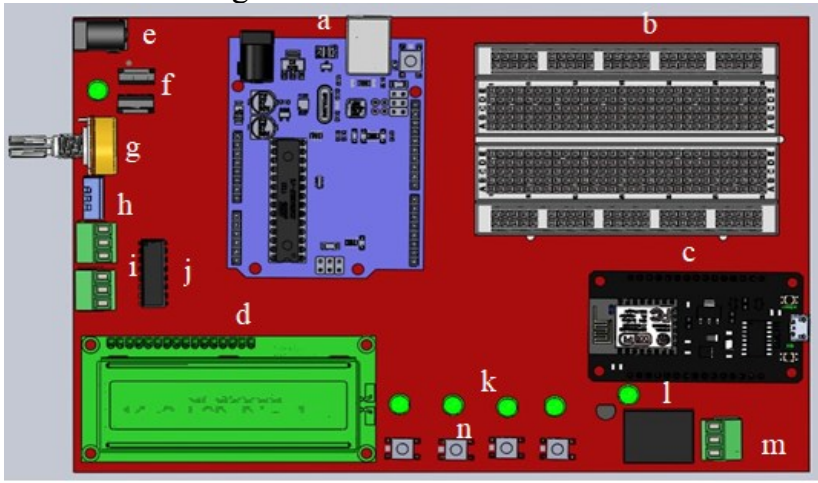

FIGURE 4. Overall Practicum Module Design 
Caption on picture 3, a) Arduino, b) Bread Board, c) NODEMCU, d) LCD, e) input voltage, f) Regulator (7805), g) Potensiometer, h) DHT11, i) Pin out dc motor, j) IC L293D, k) LED, 1) Relay, m) Pin out relay, n) Push button

\section{c. SOFTWARE DESIGN}

The programming in this study uses Arduino IDE version 1.8.14 for the Arduino Uno R3 microcontroller, Ethernet Shield and NodeMCU. The programming stage starts from the acquisition of the DHT11 sensor data and is displayed on the LCD and de motor control, then using keypad input for servo motor control can be seen in program listing 1 .
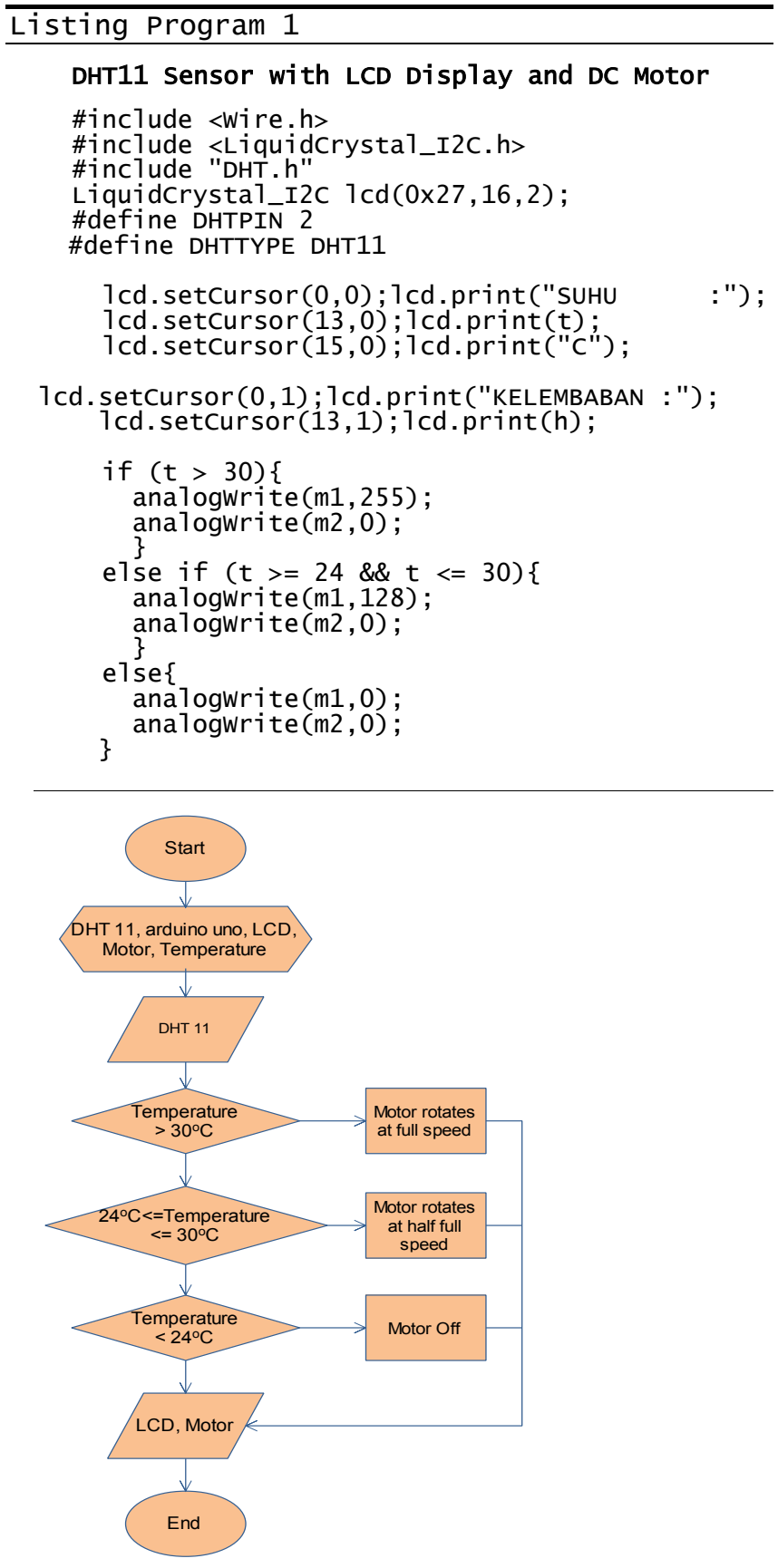

FIGURE 5. Flowchart of DHT11 circuit, LCD and DC Motor to Arduino

Based on Figure 5, it can be explained that the programming starts from the initialization of DHT-11, LCD, temperature and motor. The input is DHT-11, the data issued by DHT-11 is in the form of temperature, where 3 conditions are made, namely when Temperature $>30$ then the motor will rotate in full condition, then if $24<=$ Temperature $<=30$ then the motor will rotate with the condition slowly, and the last condition is if the temperature is $<24$ then the motor will die. All processed data will be displayed on LCD and Motor.

The next programming stage is controlling DC motors and relays using NodeMCU with wireless communication and HTTP protocol. The display on the browser can be seen in Figure 6. The program listing can be seen in the program listing 2 .

\section{Kontrol Led Dan Motor Melalui Browser}
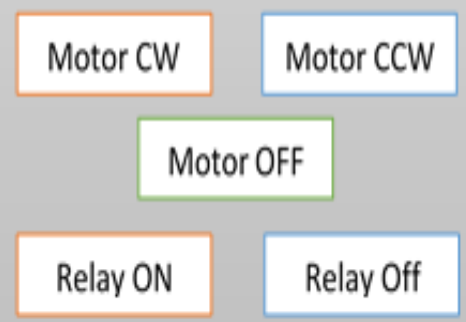

FIGURE 6. Motor Control and Relay Display in Browser

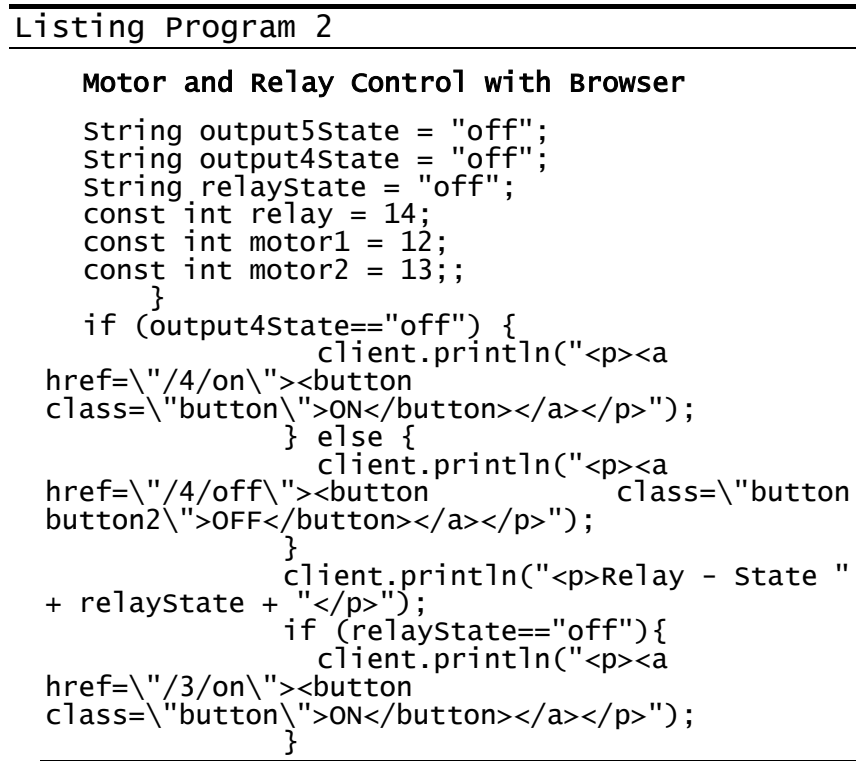

Accredited by Ministry of Research and Technology /National Research and Innovation Agency, Indonesia 
Details of the cost and use of materials in the manufacture of practical embedded systems and IoT modules can be seen in table 1 . Based on table 1, it can be seen that the total cost for the practical module materials made is Rp. 440,000 with materials and materials that are cheap and widely sold.

TABLE 1

Materials Embedded systems and IoT practicum modules

\begin{tabular}{lll}
\hline \hline Devices/Material & Qty & $\begin{array}{l}\text { Harga } \\
(\mathrm{Rp})\end{array}$ \\
\hline Arduino Uno & 1 & 70.000 \\
\hline NodeMCU & 1 & 45.000 \\
\hline Ethernet Shield & 1 & 60.000 \\
\hline Breadboard & 1 & 20.000 \\
\hline LCD 2x16 & 1 & 35.000 \\
\hline DHT 11 & 1 & 25.000 \\
\hline Potensiometer & 1 & 10.000 \\
\hline Regulator (7805) & 1 & 5.000 \\
\hline Jack DC & 1 & 4.000 \\
\hline Pin Out Motor & 1 & 5.000 \\
\hline IC L293D & 1 & 25.000 \\
\hline LED & 6 & 6.000 \\
\hline
\end{tabular}

\section{B. PERFORMANCE TESTING OF EMBEDDED SYSTEM AND IOT MODULES}

The tests started from testing on the embedded system section and then continued with wireless network data communication using the http protocol. The practical module that has been made is shown in Figure 7. Figures $8 \mathrm{a}, 8 \mathrm{~b}$ and $8 \mathrm{c}$ are the results of the performance test of the embedded system module which consists of an output, input and Analog Digital Converter (ADC) circuit.

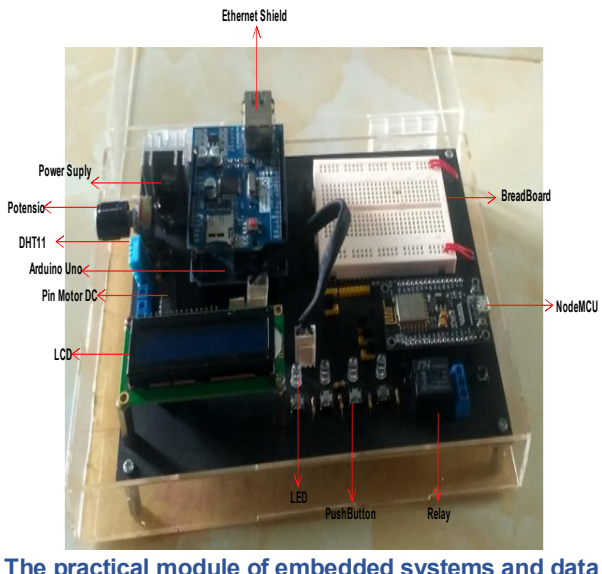

FIGURE 7. The practical module of embedded systems and data

The test in this section is based on program listing 1 to verify that the components in the output section are working properly consisting of LEDs, LCDs, DC motors and servo motors. The LCD uses I2C LCD, this module is controlled serially in sync with the I2C/IIC protocol. (inter integrated circuit) or TWI (Two Wire interface) with addresses $0 \times 27$ and 0x37. To control the DC motor, the motor driver IC L293D is used. The $\mathrm{EN} 1$ pin is a pin that is used to enable the DC motor (ON/OFF DC motor), therefore the EN1 pin is connected to the PWM output of the Arduino module. The DC motor test table on the practical module can be seen in table 2 .

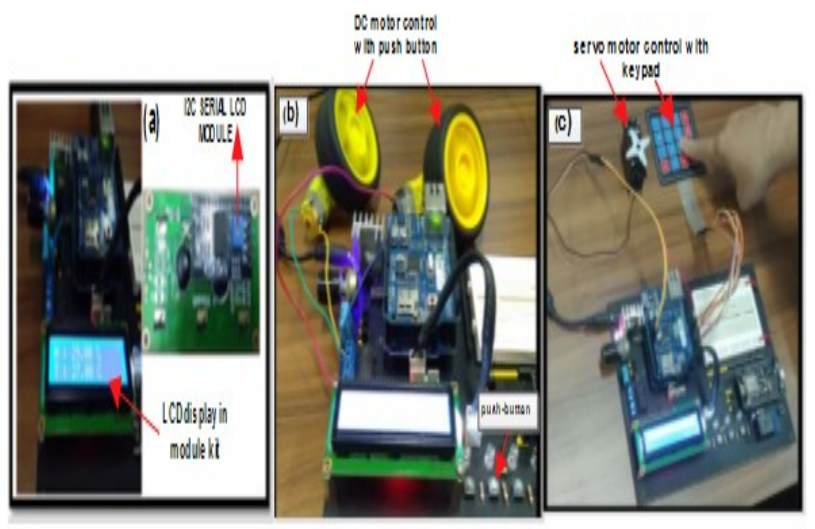

FIGURE 8. Performance test of the designed module kit: (a) image of LCD display and I2C module LCD; (b) Picture of DC motor control with push button; (c) Picture of servo control with keypad

TABLE 2

DC motor pwm measurement

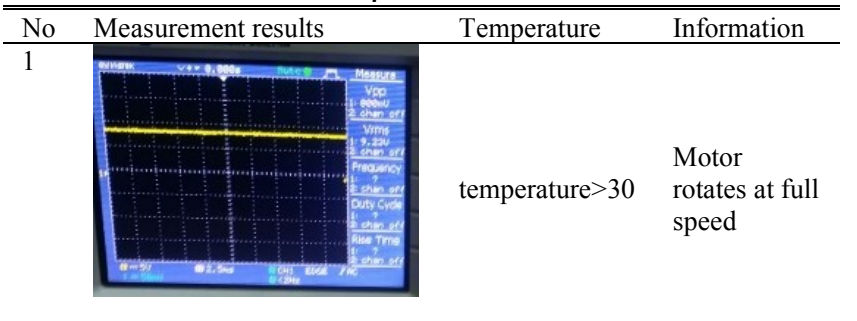

2

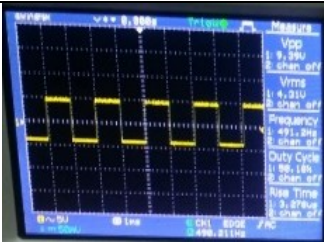

$\begin{array}{cl}24<= & \begin{array}{l}\text { Motor } \\ \text { rotates at } \\ \text { half full } \\ \text { temperature }\end{array} \\ <=30 & \text { speed }\end{array}$

3

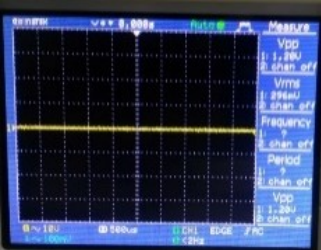

temperature

$<24$

Motor Off

Based on table 2, it can be explained that the waves obtained when the motor is full speed are in the form of a straight line with a voltage of $9.23 \mathrm{~V}$, while when the motor is at half speed, the PWM pulse wave is obtained as shown in table 2 with a voltage of $4.31 \mathrm{~V}$. Meanwhile, when the motor is off, the voltage becomes 0 . $\mathrm{V}$ with straight waves according to table 2. Servo motor with keypad as a control device to control the servo motor as shown in Figure 8c. The program loaded into the embedded system module is when button 2 is pressed the servo motor rotates at position $20^{\circ}$, when button 4 is pressed the servo motor rotates at position $40^{\circ}$, when button 9 is 
pressed the servo motor rotates at position $90^{\circ}$, and when button 0 is pressed the servo motor rotates at position $0^{\mathrm{O}}$.

TABLE 3

Servo Motor Program Logic with Keypad as Control Device

\begin{tabular}{cc}
\hline \hline Keypad & Servo \\
\hline 0 & $0^{\circ}$ \\
\hline 2 & $20^{\circ}$ \\
\hline 4 & $40^{\circ}$ \\
\hline 9 & $90^{\circ}$ \\
\hline
\end{tabular}

Furthermore, testing the module for data communication, the object of this test is to implement NodeMCU as a server for controlling DC motors. The circuit drawing can be seen in Figure 3 and the programming in the program listing 2. The configuration design of the detailed communication relationship between hardware and the internet network can be seen in Figure 9.

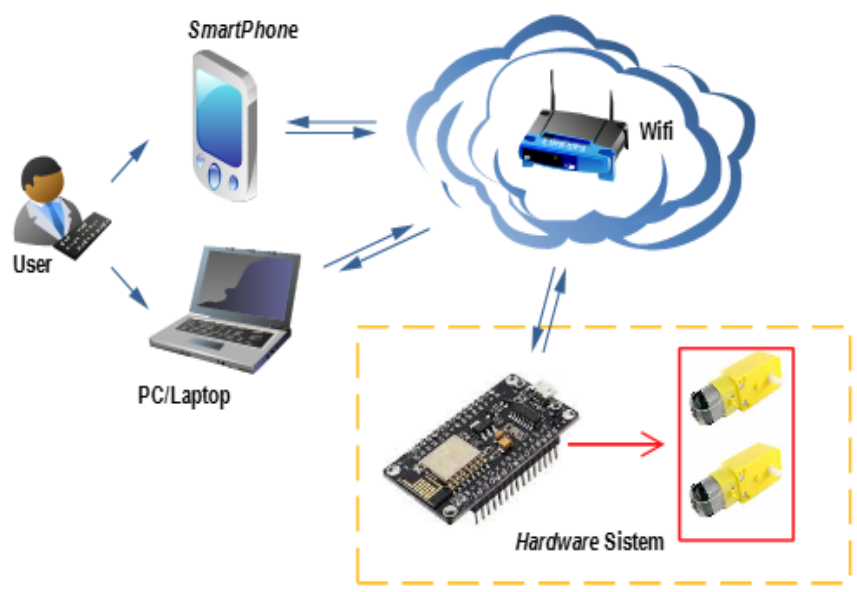

FIGURE 9. Communication System Design

The test is carried out by giving the $\mathrm{CW} / \mathrm{CCW}$ command for the $\mathrm{DC}$ motor, if the $\mathrm{CW}$ button is pressed the motor will rotate clockwise, if the CCW motor is pressed, the motor will rotate counterclockwise. For the Relay ON/OFF command to activate the relay in OPEN and Normaly CLOSE (NC) conditions. The test results can be seen in Table 4 .

TABLE 4

Testing Applications for Controlling DC Motors and Relays based on Mobile Web

\begin{tabular}{lll}
\hline \hline Testing Button & Perintah & Testing result \\
\hline Button CW & Motor CW & Working properly \\
\hline Button CCW & MotorCCW & Working properly \\
\hline Button Motor OFF & Motor Off & Working properly \\
\hline Button Relay ON & Relay OPEN & Working properly \\
\hline Button Relay OFF & $\begin{array}{l}\text { Relay Normaly } \\
\text { CLOSE (NC) }\end{array}$ & Working properly \\
\hline
\end{tabular}

Based on the test results, the application is designed to be able to control the motor and relay, although there is still a delay in sending data, this is due to the condition of the internet network at the time of testing.
In terms of performance, the pratikum module that has been created provides reliable performance from the test results of embedded systems and data communication through control scenarios using the mobile web.

\section{OVERALL PRACTICUM MODULE TESTING RESULTS}

Furthermore, observations and testing of the module as a whole are carried out from a series of inputs, outputs, sensors and network-based data communications that are adapted to student practicum jobs, which can be seen in table 5 .

TABLE 5

Overall Practicum Module Testing Results

\begin{tabular}{|c|c|c|c|}
\hline Practical Job & Expected & $\begin{array}{l}\text { Observation } \\
\text { and testing }\end{array}$ & Information \\
\hline $\begin{array}{c}\text { Control } \\
\text { application } \\
\text { with keypad } \\
\text { input, push } \\
\text { button, sensor }\end{array}$ & $\begin{array}{l}\text { Keypad, push } \\
\text { button and } \\
\text { sensor can } \\
\text { control LED, } \\
\text { LCD, dc motor } \\
\text { and servo } \\
\text { motor }\end{array}$ & $\begin{array}{c}\text { Keypad, } \\
\text { push button } \\
\text { and sensor } \\
\text { can control } \\
\text { LED, LCD, } \\
\text { dc motor and } \\
\text { servo motor }\end{array}$ & $\begin{array}{l}\text { Working } \\
\text { properly }\end{array}$ \\
\hline $\begin{array}{l}\text { LED display } \\
\text { application, } \\
\text { DC motors, } \\
\text { LCD and } \\
\text { Servo motors }\end{array}$ & $\begin{array}{c}\text { LED,LCD can } \\
\text { be displayed } \\
\text { and Servo } \\
\text { motor, DC } \\
\text { motor can } \\
\text { rotate }\end{array}$ & $\begin{array}{l}\text { LED,LCD } \\
\text { can be } \\
\text { displayed } \\
\text { and Servo } \\
\text { motor, DC } \\
\text { motor can } \\
\text { rotate } \\
\end{array}$ & $\begin{array}{l}\text { Working } \\
\text { properly }\end{array}$ \\
\hline $\begin{array}{l}\text { Web-based } \\
\text { monitoring } \\
\text { system } \\
\text { application }\end{array}$ & $\begin{array}{c}\text { NodeMCU } \\
\text { and Ethernet } \\
\text { can function as } \\
\text { a webclient }\end{array}$ & $\begin{array}{c}\text { NodeMCU } \\
\text { and Ethernet } \\
\text { can function } \\
\text { as a } \\
\text { webclient }\end{array}$ & $\begin{array}{l}\text { Working } \\
\text { properly }\end{array}$ \\
\hline $\begin{array}{l}\text { Web-based } \\
\text { control } \\
\text { system } \\
\text { application }\end{array}$ & $\begin{array}{c}\text { NodeMCU } \\
\text { and Ethernet } \\
\text { can function as } \\
\text { a server }\end{array}$ & $\begin{array}{l}\text { NodeMCU } \\
\text { and Ethernet } \\
\text { can function } \\
\text { as a server }\end{array}$ & $\begin{array}{l}\text { Working } \\
\text { properly }\end{array}$ \\
\hline
\end{tabular}

From table 5 it can be seen that the tests were carried out based on student practicum jobs on each input series, and the output results were that all applications tested were successful as expected.

\section{DISCUSSION}

Embedded systems and IoT are subjects studied in the electronics engineering curriculum. The ability of students to apply embedded systems is needed, especially in the world of work. Laboratory practice is an important activity for vocational education. Limited equipment is a major problem for students, causing students to not be able to experience learning. The learning process is not optimal because laboratory equipment is inadequate [27]. The embedded systems and IoT practicum module is designed to train students to understand the basic and advanced logic of microcontroller and IoT input and output processes. The 
dimensions of the module are $20 \times 15 \mathrm{~cm}$ at a low cost with a power consumption of 13.5 watts. The comparison of features of the traditional kit module [22][28] with the designed Edukit module is shown in table 6 .

This module consists of Arduino as a microcontroller integrated with Ethernet shield and nodemcu as data communication to the internet network. To measure its performance, this module was tested in practical activities. The control of dc motors and relays provides an overview of the process of basic dc motors and control systems [29]. The combination of a keypad and a servo motor explains the basic concept of authentication via a password with a keypad [30]. Monitoring of temperature and humidity provides an overview of the process of data acquisition and data communication using the http protocol [31]. The features of this module are not only used by electronic engineering but can also be used by students of computer engineering, informatics engineering and electrical engineering. The circuit layout in this module is very informative. This module can be used by students to create innovative applications based on embedded systems and IoT that will lead to the creation of technology.

TABLE 6

Comparison between the traditional and module-based edukit

\begin{tabular}{ll}
\hline \hline $\begin{array}{l}\text { Module Embedded system and IoT } \\
\text { base Edukit }\end{array}$ & Traditional Edukit \\
\hline Not in a single size big PCB & single size big PCB \\
\hline Low cost & expensive \\
\hline Use is simple & Use is complex \\
\hline $\begin{array}{l}\text { Integrated with LAN and Wireless } \\
\text { network modules }\end{array}$ & Not integrated \\
\hline $\begin{array}{l}\text { MCU port pin is free for any } \\
\text { application. }\end{array}$ & MCU port pin is fixed \\
\hline
\end{tabular}

\section{CONCLUSION}

In this study, a simple, inexpensive and portable laboratory kit module was developed for use in embedded systems and IoT practicums. Test results DHT 11 temperature sensor can read the index of temperature and humidity whose data is in the form of digital data and displayed on the LCD. The PWM of the DC motor and the direction of rotation of the motor can be controlled using a DHT 11 temperature sensor. The keypad can control the direction of rotation of the servo motor so that students are expected to provide authentication via a password with a keypad. Testing the kit module for data communication using a local network is able to control motors and relays although there are still delays in sending data this is due to the condition of the internet network at the time of testing. The overall test results are as expected.

\section{REFERENCES}

[1] Ananda Mohon Ghosh; Debashish Halder; S K Alamgir Hossain.2016. Remote health monitoring system through IoT, 5th International Conference on Informatics, Electronics and Vision (ICIEV).
[2]. Sarfraz Fayaz Khan, Health care monitoring system in Internet of Things (IoT) by using RFID, 2017 6th International Conference on Industrial Technology and Management (ICITM)

[3] L. Lamidi, A. Kholiq, and M. Ali, "A Low Cost Baby Incubator Design Equipped with Vital Sign Parameters", ijeeemi, vol. 3, no. 2, pp. 53-58, May 2021.

[4] A. Cholid, H. Ariswati, and S. Syaifudin, "Digital Pressure Meter Equipped with Temperature and Humidity", ijeeemi, vol. 2, no. 1, pp. 1-5, Feb. 2020

[5] M. Islam et al., "Android based heart rate monitoring and automatic notification system," 5th IEEE Reg. 10 Humanit. Technol. Conf. 2017, R10-HTC 2017, vol. 2018-Janua, pp. 436-439, 2018, doi: 10.1109/R10-HTC.2017.8288993.

[6] M. I. Sani, G. A. Mutiara, and R. S. D. W. Putra, "Fit-NES: wearable bracelet for heart rate monitoring," TELKOMNIKA (Telecommunication Comput. Electron. Control., vol. 17, no. 1, p. 392, 2019, doi: 10.12928/telkomnika.v17i1.11611.

[7] H. Yuliandoko, Subono, V. A. Wardhany, S. H. Pramono, and P Siwindarto, "Design of flood warning system based IoT and water characteristics," Telkomnika (Telecommunication Comput. Electron. Control., vol. 16, no. 5, pp. 2101-2110, 2018, doi: 10.12928/TELKOMNIKA.v16i5.7636.

[8] E. Madona, M. Irmansyah, and A. Nasution, "Design Dan Implementasi Wireless Sensor Network Pada Prototype Pendeteksian Material Galodo," vol. 11, pp. 39-42, 2019.

[9] J. Lee, I. Khan, S. Choi, and Y. W. Kwon, "A smart iot device for detecting and responding to earthquakes," Electron., vol. 8, no. 12, pp. 1-19, 2019, doi: 10.3390/electronics8121546.

[10] S. K. Bhoi et al., "FireDS-IoT: A Fire Detection System for Smart Home Based on IoT Data Analytics," Proc. - 2018 Int. Conf. Inf. Technol. ICIT 2018, pp. 161-165, 2018, doi: 10.1109/ICIT.2018.00042.

[11] J. Bauer and N. Aschenbruck, "Design and implementation of an agricultural monitoring system for smart farming," 2018 IoT Vert. Top. Summit Agric. - Tuscany, IOT Tuscany 2018, pp. 1-6, 2018, doi: 10.1109/IOT-TUSCANY.2018.8373022.

[12] S. R. Prathibha, A. Hongal, and M. P. Jyothi, "IOT Based Monitoring System in Smart Agriculture," Proc. - 2017 Int. Conf. Recent Adv. Electron. Commun. Technol. ICRAECT 2017, pp. 81-84, 2017, doi: 10.1109/ICRAECT.2017.52.

[13] "IoT-based Intelligent Irrigation Management and Monitoring System using Arduino," TELKOMNIKA (Telecommunication Comput. Electron. Control., vol. 17, no. 5, pp. 2378-2388, 2019, doi: 10.12928/telkomnika.v17i5.12818.

[14 H. P. Breivold and K. Sandstrom, "Internet of Things for Industrial Automation-Challenges and Technical Solutions," Proc. - 2015 IEEE Int. Conf. Data Sci. Data Intensive Syst. 8th IEEE Int. Conf. Cyber, Phys. Soc. Comput. 11th IEEE Int. Conf. Green Comput. Commun. 8th IEEE Inte, pp. 532-539, 2015, doi: 10.1109/DSDIS.2015.11

[15] A. Caputo, G. Marzi, and M. M. Pellegrini, "The Internet of Things in manufacturing innovation processes," Bus. Process Manag. J., vol. 22, no. 2, pp. 383-402, 2016, doi: 10.1108/bpmj-05-2015-0072.

[16] H. W. Picot, M. Ateeq, B. Abdullah, and J. Cullen, "Industry 4.0 labview based industrial condition monitoring system for industrial iot system," Proc. - Int. Conf. Dev. eSystems Eng. DeSE, vol. October-2019, pp. 1020-1025, 2019, doi: 10.1109/DeSE.2019.00189.

[17] P Koopman, et al. Undergraduate Embedded System Education at Carnegie Mellon. ACM Trans. Embed. Comput. Syst. 2005; 4(3): 500528.

[18] J. P. Mendoza, J. M. V. Carrizo, and F. J. R. Sánchez, "Project based learning experiences for embedded systems design," Proc. 2016 Technol. Appl. to Electron. Teaching, TAEE 2016, 2016, doi: 10.1109/TAEE.2016.7528370.

[19] C. L. C. Bual, R. D. Cunanan, R. A. R. Bedruz, A. A. Bandala, R. R. P. Vicerra, and E. P. Dadios, "Design of Controller and PWM-enabled DC Motor Simulation using Proteus 8 for Flipper Track Robot," 2019 IEEE 11th Int. Conf. Humanoid, Nanotechnology, Inf. Technol. Commun. Control. Environ. Manag. HNICEM 2019, no. 1, pp. 1-5, 2019, doi: 10.1109/HNICEM48295.2019.9072736

[20] P. Bhadani and V. Vashisht, "Soil moisture, temperature and humidity measurement using arduino," Proc. 9th Int. Conf. Cloud Comput. Data 
Sci. Eng. Conflu. 2019, pp. 567-571, 2019, doi: 10.1109/CONFLUENCE.2019.8776973.

[21] P. Sutyasadi and M. B. Wicaksono, "Joint control of a robotic arm using particle swarm optimization based $\mathrm{H} 2 / \mathrm{H} \infty$ robust control on arduino," Telkomnika (Telecommunication Comput. Electron. Control., vol. 18, no. 2, pp. 1021-1029, 2020, doi: 10.12928/TELKOMNIKA.V18I2.14749.

[22] Indrianto, M. N. I. Susanti, R. Arianto, and R. R. A. Siregar, "Embedded system practicum module for increase student comprehension of microcontroller," Telkomnika (Telecommunication Comput. Electron. Control., vol. 16, no. 1, pp. 53-60, 2018, doi: 10.12928/TELKOMNIKA.v16i1.4194.

[23]. R. Sistem, "Penerapan Rangkaian Simulasi Terintegrasi Untuk Efisiensi Penggunaan," vol. 1, no. 10, pp. 4-8, 2021.

[24] Deaky, B., Lupulescu, N. B., \& Ursutiu, D. (2011). Extended educational use of the Microcontroller Student Learning Kit (MCU SLK). 2011 IEEE Global Engineering Education Conference, EDUCON 2011, May 2011, 913-916. https://doi.org/10.1109/EDUCON.2011.5773254

[25] H. G. Espinosa and D. V. Thiel, "MATLAB-Based interactive tool for teaching electromagnetics [education corner]," IEEE Antennas Propag. Mag., vol. 59, no. 5, pp. 140-146, 2017, doi: 10.1109/MAP.2017.2731218.

[26] M. Taruk and A. Ashari, "Analisis Throughput Varian TCP Pada Model Jaringan WiMAX," IJCCS (Indonesian J. Comput. Cybern. Syst., vol 10, no. 2, p. 115, 2016, doi: 10.22146/ijccs. 15529 .

[27] A. G. Abdullah, D. L. Hakim, M. A. Auliya, A. B. D. Nandiyanto, and L. S. Riza, "Low-cost and portable process control laboratory kit," Telkomnika (Telecommunication Comput. Electron. Control., vol. 16 no. 1, pp. 232-240, 2018, doi: 10.12928/TELKOMNIKA.v16i1.6888.

[28] L. Ali, L. Rahman, and S. Akhter, "Module-based Edukit for teaching and learning 8051 microcontroller programming," 2nd IEEE Int. Conf. Telecommun. Photonics, ICTP 2017, vol. 2017-December, no. February 2018, pp. 57-61, 2018, doi: 10.1109/ICTP.2017.8285918.

[29] M. R. C. Reis et al., "Speed control for direct current motor using optimization tuning for PID controller," EEEIC 2016 - Int. Conf. Environ. Electr. Eng., pp. 3-6, 2016, doi: 10.1109/EEEIC.2016.7555596.

[30] E. Z. Orji, U. I. Nduanya, and C. V Oleka, "Microcontroller Based Digital Door Lock Security System Using Keypad," Int. J. Latest Technol. Eng. Manag. I\& Appl. Sci., vol. 8, no. 1, pp. 92-97, 2019.

[31] Y. Wang and Z. Chi, "System of wireless temperature and humidity monitoring based on Arduino Uno platform," Proc. - 2016 6th Int. Conf Instrum. Meas. Comput. Commun. Control. IMCCC 2016, pp. 770 773, 2016, doi: 10.1109/IMCCC.2016.89. 